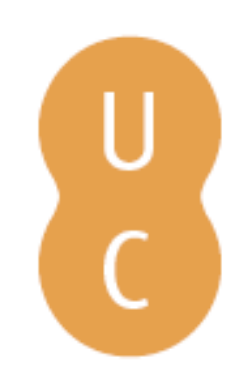

\title{
nombalina
}

\section{Utopia e diálogo na arte grega}
Autor(es):
Morais, Rui
Publicado por: Imprensa da Universidade de Coimbra
URL persistente:
URI:http://hdl.handle.net/10316.2/32062
DOI:
DOI:http://dx.doi.org/10.14195/978-989-26-0499-2_14

Accessed : $\quad$ 26-Apr-2023 13:56:04

A navegação consulta e descarregamento dos títulos inseridos nas Bibliotecas Digitais UC Digitalis, UC Pombalina e UC Impactum, pressupõem a aceitação plena e sem reservas dos Termos e Condições de Uso destas Bibliotecas Digitais, disponíveis em https://digitalis.uc.pt/pt-pt/termos.

Conforme exposto nos referidos Termos e Condições de Uso, o descarregamento de títulos de acesso restrito requer uma licença válida de autorização devendo o utilizador aceder ao(s) documento(s) a partir de um endereço de IP da instituição detentora da supramencionada licença.

Ao utilizador é apenas permitido o descarregamento para uso pessoal, pelo que o emprego do(s) título(s) descarregado(s) para outro fim, designadamente comercial, carece de autorização do respetivo autor ou editor da obra.

Na medida em que todas as obras da UC Digitalis se encontram protegidas pelo Código do Direito de Autor e Direitos Conexos e demais legislação aplicável, toda a cópia, parcial ou total, deste documento, nos casos em que é legalmente admitida, deverá conter ou fazer-se acompanhar por este aviso.

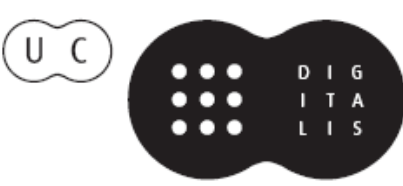


Maria de Fátima Silva

Coordenação

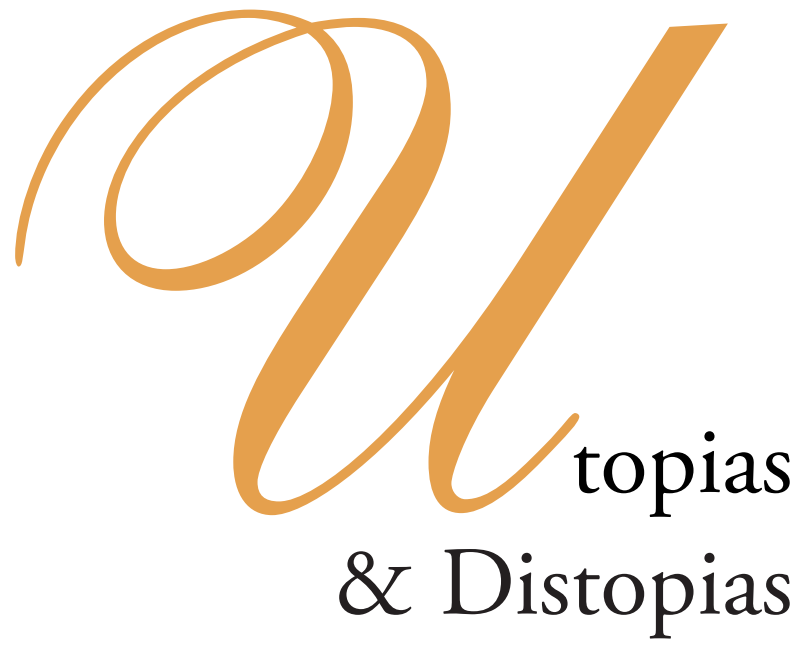




\section{COORDENAÇÃO EDITORIAL \\ Imprensa da Universidade de Coimbra \\ Email: imprensauc@ci.uc.pt \\ URL: http://www.uc.pt/imprensa_uc}

\section{CONCEPÇÃO GRÁFICA}

António Barros

Pré-IMPRESSÃo

Tipografia Lousanense, Lda.

EXECUÇÃO GRÁFICA

Tipografia Lousanense, Lda.

ISBN

978-989-8074-74-4

DEPósito LEGAL

289002/09

OBRA PUBLICADA COM O APOIO DE:

Centro de Estudos Clássicos e Humanísticos

Faculdade de Letras da Universidade de Coimbra

FCT Fundação para a Ciência e a Tecnologia

MINISTÉRIO DA CIÊNCIA, TECNOLOGIA E ENSINO SUPERIOR Portugal 
Maria de Fátima Silva

Coordenação
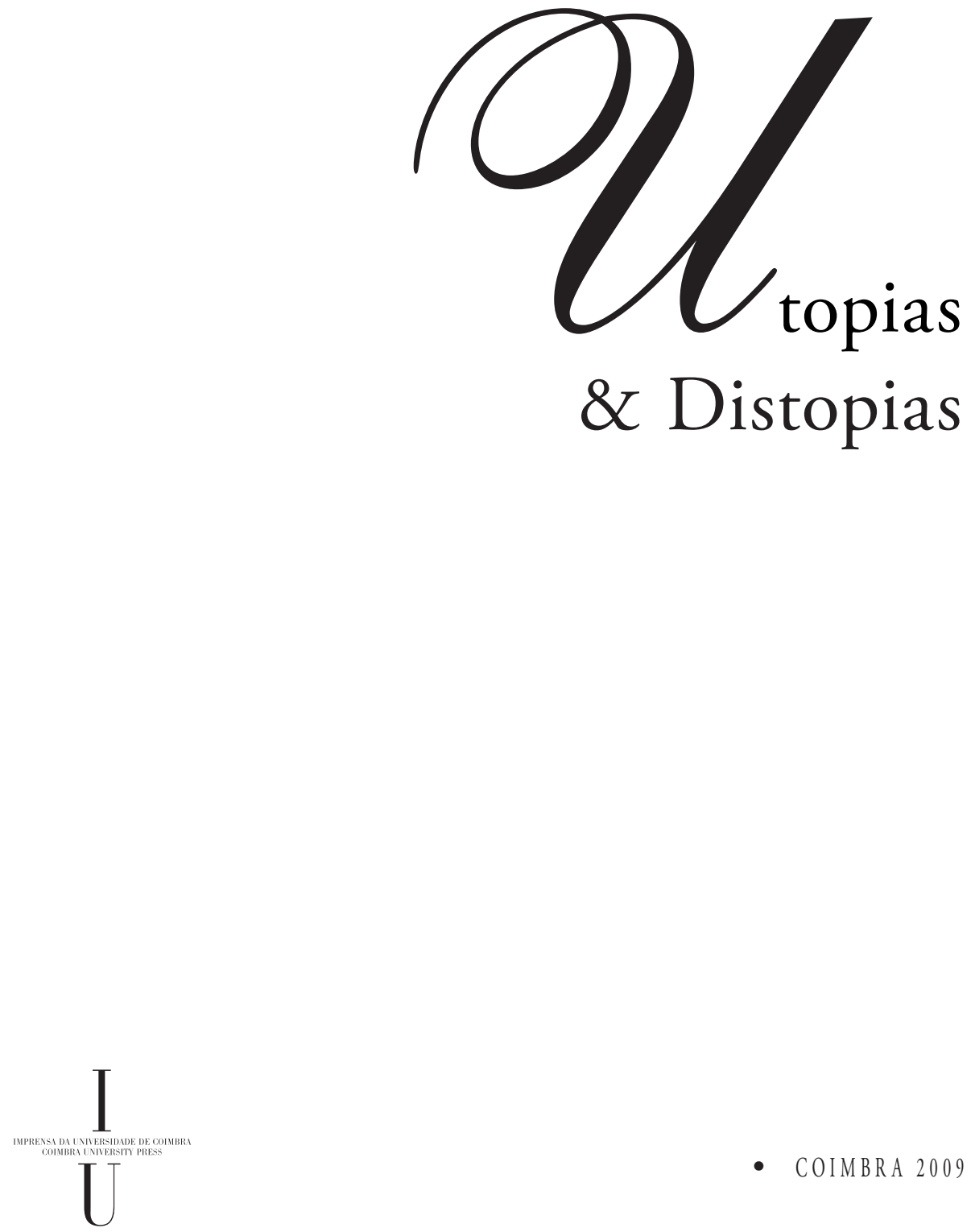

- colmbra 2009 

A utopia dialoga com o mito. A utopia, apesar de ser uma entidade intrinsecamente dialéctica, partilha muitas das características dos mitos, sobretudo no que respeita a situaçôes ideais, fictícias, superiores e qualitativamente diferentes do mundo real. Ambos possuem um carácter autónomo e externo que lhes permite construir um mundo alienado, ideal, apoiado numa universalidade abstracta, distanciada do mundo real.

Neste breve estudo pretendemos apresentar algumas representaçôes artísticas de âmbito mitológico que ilustram o tema da utopia. Mas, antes de avançarmos nessa análise, devemos perguntar-nos como é que os gregos encaram o fenómeno em si mesmo. A questão não tem resposta imediata e, em boa verdade, apenas poderemos fazer uma ideia aproximada.

Quando se tratava de deuses e de heróis, a única fonte de conhecimento era o "diz-se", uma fonte com misteriosa autoridade, certamente inspirada pelas Musas. Como nos alerta Hesíodo na abertura da Teogonia (vv. 27-28) também estas proclamavam falsidades. Mas convém salientar que a distinção clara entre poesia e verdade vai estabelecer-se pela primeira vez com este poeta. A sua obra distingue-se pelo seu carácter didáctico, afirmando que é a verdade que vai ensinar (vd. Rocha-Pereira, $200610^{a}$ ed., p. 157). A invocação às Musas faz-se também no famoso fragmento de Sólon, quando este apela às belas filhas de Mnemósine e de Zeus Olímpico, as Musas Piérides, para escutar a sua prece e conceder-lhe boa fama perante os homens (frg. 13 West, apud Rocha-Pereira, 2003, p. 135).

É interessante notar as diferentes atitudes dos gregos perante os mitos. Xenófanes, filósofo do séc. VI-V a. C., critica quanto há de vergonhoso e censurável, nos roubos, adultérios e mentiras atribuídos aos deuses por Homero e Hesíodo (frg. 11 Diels and Kranz, apud Rocha-Pereira, 2003, p. 149). O historiador e geógrafo grego Hecateu de Mileto é igualmente claro nas suas intenções e atitude crítica perante os mitos: apenas pretende contar a verdade, "pois as histórias dos gregos são", em seu entender, "muitas e ridículas" (frg. 1 a Jacoby, apud Rocha-Pereira, 2003, p. 157).

Píndaro, na sua I Ode Olimpica (vv. 52-55, apud Rocha-Pereira, 2003, p. 183), dedicada a Hierão de Siracusa, vencedor na corrida de cavalos, recusa-se a aceitar a versão do mito que responsabilizava os deuses pelo acto atroz de Tântalo.

Mas não menos expressiva é a opinião de Platão. Em diversos passos da sua obra, sobretudo na República, faz uma crítica violenta das histórias que geralmente as amas 
e as mães contavam às crianças. Como fez salientar Rocha-Pereira, num estudo intitulado "O mito na antiguidade clássica" (2004, pp. 15-16), estas histórias, em particular os Livros II e III, são sobretudo as de Homero e Hesíodo. Mas estes mitos são substituídos por outros que deverão servir para educar os habitantes da cidade ideal (id., ibidem).

No âmbito da arte grega, recorremos a Pausânias para ilustrar esta ideia. Chegado ao livro oitavo, este escreve a dado momento (Descrição da Grécia VIII, 8, 3): "No princípio das minhas investigaçôes, não via mais do que tola credulidade nos nossos mitos; mas, agora que as minhas investigaçóes incidem sobre a Arcádia, tornei-me mais prudente".

Menos crítica seria a atitude do grego médio que certamente se encantava com todo o género de narrativas, ilustradas através da arte e retomadas na vasta literatura em verso e prosa. Assim se refere a eles Pausânias no primeiro volume da referida obra (Descrição da Grécia I, 3, 3): "contam-se muitas coisas não verdadeiras na multidão, que não compreende nada da história e que julga digno de fé o que ouviu desde a infância nos coros e nas tragédias".

De facto, para a maior parte dos gregos a questão da historicidade ou ficção dos mitos náo fazia sentido. $\mathrm{O}$ mesmo se poderá dizer dos lugares utópicos por eles veiculados. Estes mundos de lendas eram entendidos como verdadeiros, no sentido em que não se duvidava deles, ainda que, naturalmente, não se acreditasse neles como nas realidades que os rodeavam. Tudo se teria passado num tempo longínquo, durante as geraçóes heróicas, altura em que os deuses ainda se misturavam com os humanos.

Mesmo a atitude crítica de Pausânias não era no sentido de demonstrar a falsidade dos mitos, mas antes de recuperar o seu fundo de verdade. Por isso narra a maior parte das lendas que lhe contaram, ainda que, por vezes, exclua a intervençáo dos deuses.

Tomemos como exemplo o tema de Hércules. Como refere Walter Burkert (1993, p. 405), Hércules era "o poderoso filho de Zeus, que pode sempre nomear a "bela vitória” como sua, é o maior dos heróis gregos, e mesmo completamente utópico”.

Pausânias duvida de muitas das façanhas atribuídas a este herói; outras aceita-as com a maior naturalidade. Não duvida, por exemplo, da existência dos pássaros do lago Estinfálio, pois, segundo este (Descrição da Grécia VIII, 22, 4), ainda podiam ver-se na Arábia; o mesmo não se poderá dizer relativamente a Cérbero, pois não há, no fundo da gruta de onde Hércules trouxera para a terra o cão do inferno "qualquer via que conduza ao subsolo, nem se deve acreditar que os deuses tenham qualquer espécie de morada subterrânea onde arrumem as almas" (Pausânias, Descrição da Grécia III, 25, 5).

A existência do herói nunca foi, porém, questionada. Ainda que alguns espíritos não acreditassem na existência dos deuses, nunca se duvidou da dos heróis; tratava-se, de facto, de seres humanos dotados de características maravilhosas e com culto próprio. Hércules era o maior entre os heróis gregos, com a singularidade de ser venerado ao mesmo tempo como deus e herói. E sobre isso não havia qualquer tipo de dúvida: ele teria passado a vida a tornar a Terra habitável; seria desautorizado que alguém questionasse a memória do seu evérgeta e lhe retirasse todo e qualquer louvor. Apenas mais tarde, Cícero ( $D e$ natura deorum III, 16, 40) questiona a divinização do herói: "Dizem-me que Hércules, de mortal que era, conseguiu tornar-se um Deus? Muito gostaria então que me explicassem como é que uma coisa foi possível outrora e já não o é hoje”. 
Hércules foi, sem dúvida, o herói mais celebrado em todos os domínios da arte grega, se não mesmo o tema mais frequentemente representado. Retratavam-se os doze trabalhos ao serviço do seu senhor, Euristeu, outros realizados por própria iniciativa e em número incerto, para além das pequenas aventuras que iam ocorrendo durante a realização dos mesmos. Uma excelente resenha da evolução da representação de Hércules na arte grega nos períodos arcaico e clássico pode ser apreciada na obra de Thomas H. Carpenter (1991). De realce são, porém, as obras de H. A. Shapiro, Myth into Art (1994), e de Frank Brommer, com dois livros de especial importância, o primeiro intitulado Herakles. Die zwölt Taten des Helden in antiker Kunst und Literatur (1953), e o segundo Vasenlisten zur griechischen Heldensage (1960, 2a ed.), com 159 páginas sobre Hércules e mais de 2500 entradas só com vasos com o tema deste herói.

Naturalmente que, para o tema que aqui nos ocupa, a utopia na arte grega, interessam-nos as expressôes artísticas relacionadas com a deificação do herói. De fora desta análise fica um sem número de obras de arte gregas relacionadas com o tema de Hércules. Refira-se, como expoente máximo das mesmas, as célebres métopas do templo de Zeus em Olímpia, que representam os trabalhos de Hércules, seis em cada lado, que, ao que se julga, terão contribuído para fixar em doze o seu número (vd. Rocha-Pereira, 2006 10a ed., pp. 595-597).

A divinização de Hércules, que incluiu a sua recepção por parte dos deuses no Olimpo, representou um exemplo transcendental na história da relação entre os deuses e os heróis, apenas comparável à figura de Diónisos (vd. Burkert, 1993, p. 399 e nota 164). À semelhança de outros lugares utópicos, como as Ilhas dos Bem-Aventurados, os Campos Elísios, ou certos locais míticos, como o Jardim das Hespérides, o Olimpo representava um local mítico, que apenas estava reservado aos deuses. A deificação de Hércules vai assim tornar o local alcançável pelos humanos, desde que reconhecidos pela assembleia dos Olímpicos. É interessante notar, no entanto, que a concepção do Olimpo se modifica da Ilíada para a Odisseia. Como fez salientar Rocha-Pereira na sua obra Concepçóes Helénicas de Felicidade no Além, de Homero a Platão (1955, pp. 105-113), o Olimpo, em vez de ser uma montanha real, situada na Tessália, de muitos píncaros e alvo de neve, passou a ser um lugar ideal onde não chove, nem neva, e onde fica dos deuses "a eterna e segura mansão" 1 .

As aventuras e façanhas de Hércules apresentam-se como um complexo em que se justapóem elementos folclóricos e mitos etiológicos. A morte deste herói é particularmente curiosa. A versão mais antiga que se conhece é aquela que é transmitida nos Catálogos hesiódicos (fr. 25, vv. 26-33 Merkelbach and West): a sua esposa Dejanira, levada pelo ciúme, envia-lhe uma túnica envenenada que o obriga a sacrificar-se numa pira: no momento da sua morte terrena, ainda a fogueira ardia, ouviu-se um forte trovão, augúrio da ascensão do herói aos céus, através das chamas. Por sua vez, no discutido final do canto XI da Odisseia (vv. 601-604) Ulisses diz que avistou a sombra de Hércules no Hades, ao passo que ele mesmo (autós) já habitava entre os deuses. Pelo contrário, a Ilíada (XVIII 117-119) afirma que nem o próprio Hércules, o mais caro filho de Zeus, pode escapar à morte.

1 A mesma ideia é expressa pela autora em Estudos de História da Cultura Clássica, I volume (2006, $10^{\mathrm{a}}$ ed., p. 119). 
Uma vez entre os deuses, Hércules reconciliou-se com Hera, a deusa da Argólida. Esta tornou-se sua mãe imortal numa cerimónia em que se simulou o nascimento do herói. A dupla natureza de Hércules é-nos transmitida por Píndaro na III Ode Nemeia (22), quando o classifica como héros theós, "herói-deus". Este paradoxo encontra confirmação no culto que lhe era prestado em várias cidades, como no caso de Tasos (uma ilha a norte do mar Egeu) onde, segundo Heródoto (Histórias II, 44), existiam dois santuários diferentes, um dedicado ao deus e outro recordando-o como herói. Deuses e heróis são venerados, ambos possuem uma esfera sacral embora com uma forma de culto diferente: fazem-se juramentos em seu nome e são-lhes dirigidas preces. Os deuses são, no entanto, mais distantes, ao contrário dos heróis, mais próximos do comum dos mortais (Burkert, 1999, pp. 399-400).

A utilização da figura do herói com fins políticos é também conhecida. Os reis dos Dórios fazem-no seu antepassado oficial. Recordemos, entre outras histórias, aquela transmitida por Plutarco (Licurgo I, 3), quando menciona que todos os reis espartanos eram tradicionalmente descendentes de Hércules. Um destes monarcas, Cleómenes, irá inclusivamente tirar partido dessa ascendência, cunhando moedas com a imagem do herói (Ferguson, 1975, p. 132). Os reis lídios, e mais tarde os macedónios, também se tornaram Heraclidas (Burkert, 1993, p. 411). A utilização da imagem de Hércules como propaganda política terá igualmente sucesso na época romana, como nos casos bem conhecidos de Marco António e Cómodo.

Para além do modelo de soberano que, em virtude da sua legitimação divina, actua para o bem do género humano, Hércules é o modelo para o homem comum que pode aspirar, após uma vida de sofrimentos, a ascender até aos deuses. Hércules é o protótipo inspirador, tornando o divino acessível aos homens (id., ibidem).

Está assim consagrado o diálogo entre a utopia e o mito. Mas analisemos de perto alguns exemplos iconográficos sugestivos destes acontecimentos.

Num frontáo de pedra calcária de um dos templos arcaicos da Acrópole de Atenas este motivo está representado: Hércules e Hermes aproximam-se de Zeus e Hera; neste frontão estaria também presente a deusa Atena, responsável por guiar o herói (fig. 1).

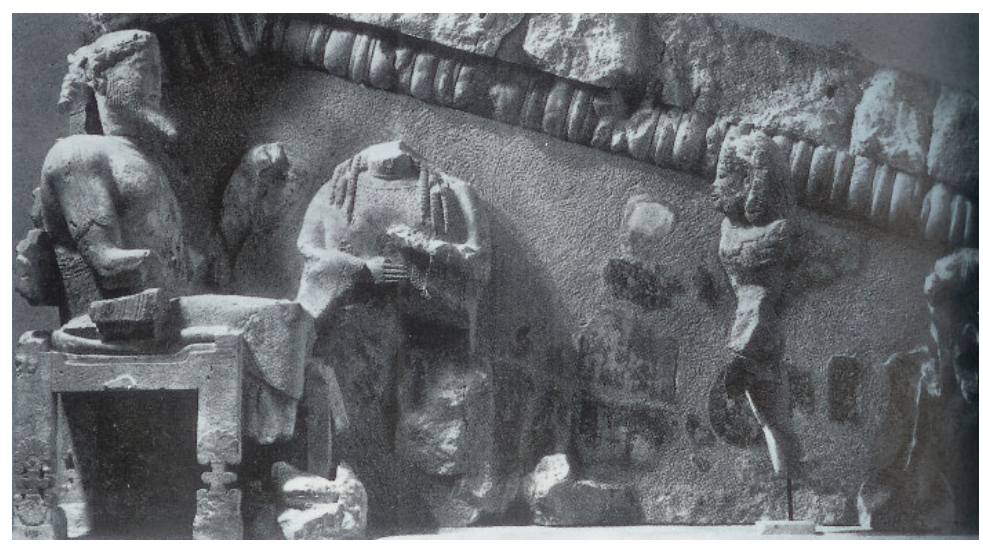

Fig.1 
Mas a maior parte dos exemplos conhecidos figuram em vasos gregos. Num arýballos coríntio (fig. 2), encontrado em Vulci, temos a boda de Hércules e Hebe. Ambos vão num carro, com Atena de pé, ostentando na mão o que parece ser uma grinalda, seguida por Afrodite que leva na mão uma romá. Em frente dos cavalos duas Cárites. Atrás destas, Hermes com caduceu (kerykeion) entre o casal olímpico, Zeus e Hera, ambos sentados num trono. Atrás do carro, em cortejo, Apolo Citaredo, a Musa Calíope e outras seis Musas.

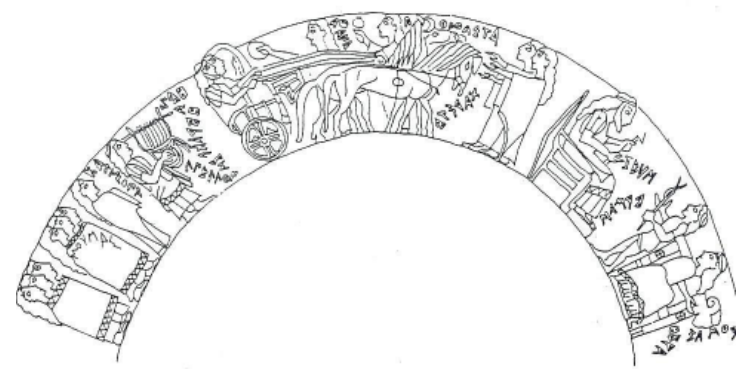

Fig. 2

Este tema é, no entanto, particularmente abundante em vasos áticos de figuras negras e de figuras vermelhas.

Numa hýdria ática de figuras negras (fig. 3) está representado um dos momentos da apoteose de Hércules: este, com a típica clava ao ombro, está num carro juntamente com a deusa Atena. Atrás deles está Diónisos com rhyton. Em frente do carro temos talvez a própria Hebe, seguida por Hermes com caduceu, ladeado por dois guerreiros com escudo (um dos quais beócio).

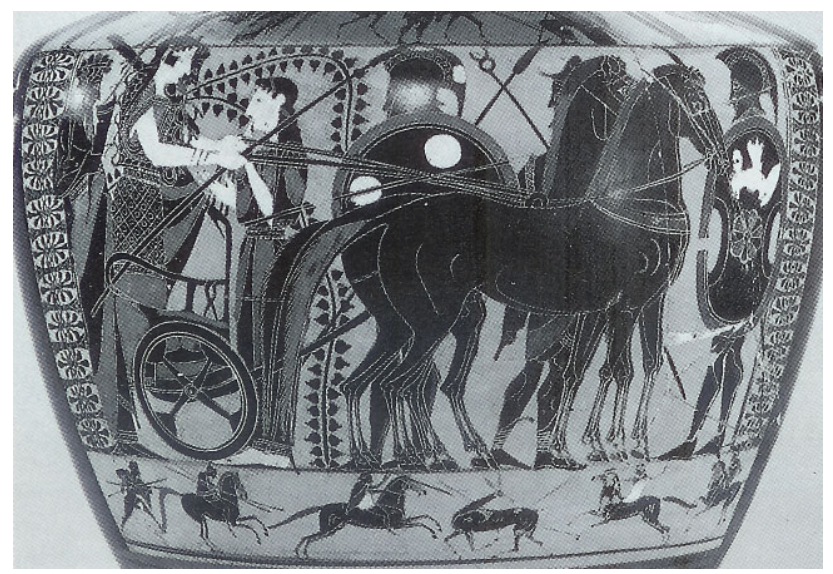

Fig.3 
Nos vasos de figuras vermelhas o exemplar que melhor ilustra a cena processional da entrada de Hércules no Olimpo é a famosa taça de Berlim, atribuída ao Pintor de Sósias. Este vaso é especialmente conhecido pela cena no seu interior, que representa Aquiles a tratar um ferimento do seu amigo Pátroclo (fig. 4). Interessa-nos, porém, a cena pintada no exterior, na qual se vê (fig. 5) a assembleia dos Olímpicos a receber Hércules. Alguns deuses reconhecem-se facilmente pelos seus atributos: Hermes com caduceu, que na sua qualidade de deus dos rebanhos e kriophoros segura nos ombros um carneiro, seguido por Apolo Citaredo, o próprio Hércules, com a pele de leão e clava, e pela deusa Atena, aqui apenas portadora da lança.
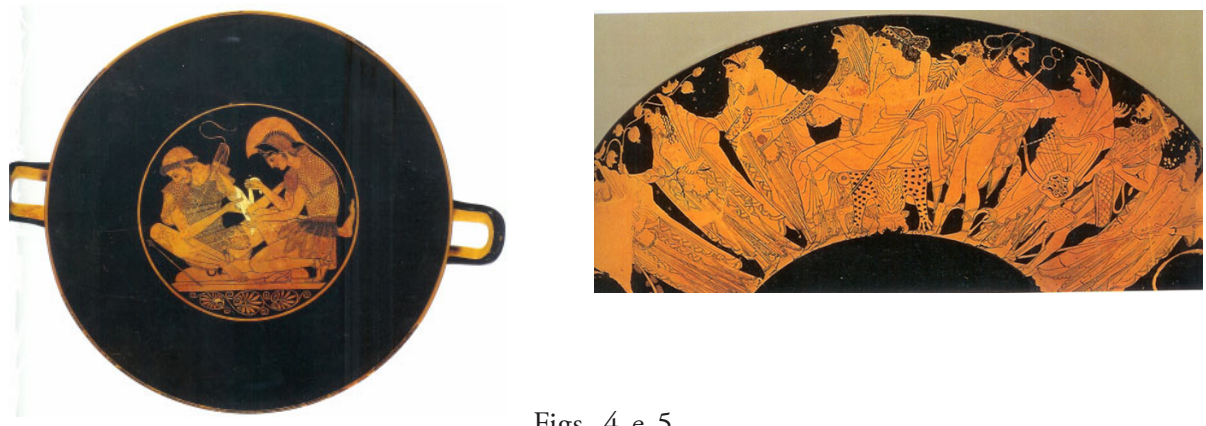

Figs. 4 e 5

Parte deste tema pode ainda ser visto numa pelike ática de figuras vermelhas datada do primeiro quartel do século V, assinada pelo Pintor de Brygos (fig. 6-8). Trata-se de um belíssimo exemplar pertencente à colecção de vasos gregos de Manuel de Lancastre, recentemente identificado e estudado no contexto da Exposição "Vasos Gregos em Portugal. Aquém das Colunas de Hércules".
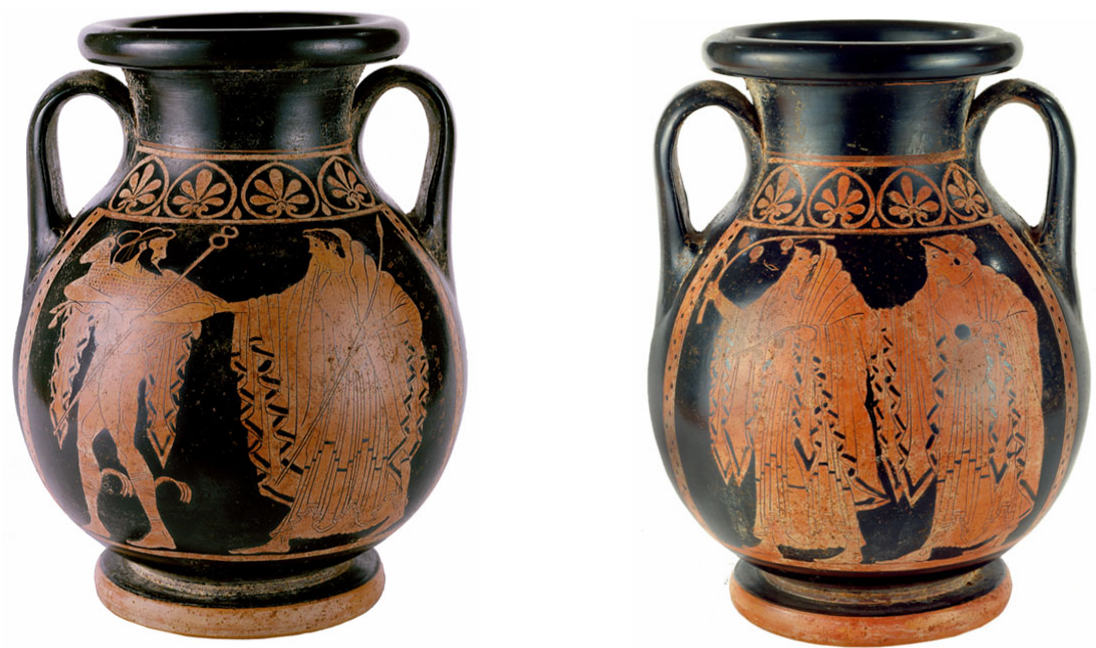

Fig. 6 e 8 
Segundo a interpretação de Rocha-Pereira (vd. Catálogo, pp. 92-93), o tema parece inspirado em cortejos de deuses, como o que decora o exterior da Taça de Berlim, acima referida. Como bem evidencia a autora, este tema foi imitado muitas vezes, com maior ou menor número de personagens. Neste caso vêem-se quatro figuras, duas no anverso e duas no reverso. No anverso temos Hermes, com os seus atributos habituais, e uma figura feminina; no reverso duas figuras femininas. Segundo a autora (id., ibidem), as três figuras femininas representam as Horas, responsáveis por presidir "ao ciclo da vegetação (embora já em Hesíodo correspondam a valores éticos, Boa Ordem, Justiça e Paz) e por isso levam romãs." A dúvida da autora, quanto à identificação da figura que caminha junto a Hermes no anverso, pelo facto de transportar uma possível lança idêntica à da deusa Atena, parece-nos muito pertinente. De facto, se a compararmos com alguns dos exemplares aqui referidos constatamos que esta deusa está sempre presente, como entidade responsável por guiar o herói. Por outro lado, pode estar representada sem capacete, como já vimos atrás (vd. fig. 3). Se aceitarmos que esta figura representa a própria Deusa, teríamos apenas duas Horas (as do reverso), o que náo coloca nenhuma dificuldade, dado que o seu número pode ser variável. Como refere a autora, com base nos exemplos reunidos no $L I M C^{2}$, pode até "reduzir-se a uma só".

Mas, independentemente de a figura poder representar ou não a deusa Atena, interessa-nos em particular a semelhança no desenho das figuras e respectivos atributos da taça do Pintor de Sósias e deste exemplar do Pintor de Brygos. Esta semelhança sugere-nos algumas breves reflexóes. De facto, se considerarmos que estas obras distam uma da outra cerca de um quarto de século, a primeira situada à volta de 510-500 a. C. e a segunda datável de 500-475 a.C., podemos supor que os artistas se tenham inspirado nalguma obra da chamada "grande pintura", de algum pintor famoso, provavelmente situada num edifício público da cidade. A ser verdade, não se trataria de um caso único. Conhecidas sáo algumas pinturas em vasos gregos como, por exemplo, o do Calyx-Kratêr do Pintor dos Nióbidas (Paris, Museu do Louvre, c. 460-450 a. C.), que parecem inspirar-se em famosas pinturas de Polignoto (fig. 9), tal como estão descritas nas fontes (Boardman, 1981, p. 164; 1993, pp. 104-106).

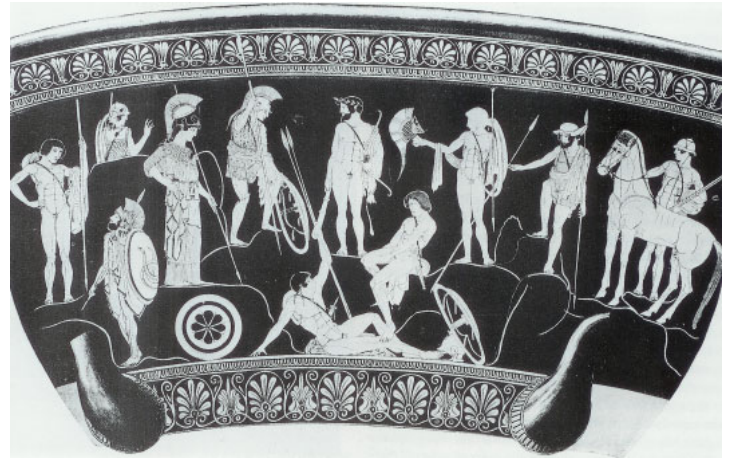

Fig. 9

2 Abreviatura de Lexicon Iconographicum Mithologiae Classicae. 
O tema da deificação de Hércules foi, como vimos, várias vezes representado, inclusivamente em época romana. Sabemos por Plínio-o-Antigo (História Natural XXXIV.218), que uma das obras mais famosas de um artista menor chamado Artémon era uma pintura que estava no pórtico de Octávia, onde se via Hércules subindo ao céu, com a aprovação dos Olímpicos que o observavam no monte Eta, perto de Trácis. Aí sabemos ter havido um lugar de culto em honra do herói, que incluía um sacrifício taurino e jogos ${ }^{3}$ (Burkert, 1993, p. 140).

Não nos deve parecer estranha esta ideia de diálogo e de inspiração entre os artistas. No caso específico dos vasos gregos são conhecidos casos em que os pintores ilustraram famosas esculturas na antiguidade. Damos por exemplo um vaso de figuras vermelhas de cerca de 440 a. C. no qual se representa uma das mais famosas esculturas de Míron (fig. 10). Sobre esta escultura fala-nos Plínio (História Natural XXXIV.57) e Pausânias (Descrição da Grécia I.24.1) que descrevem o sátiro Mársias atraído pela flauta ou aulos deitada ao chão pela deusa Atena (fig. 11). Quer na ilustração do vaso, quer na cópia romana deste conjunto escultórico, está bem patente a atitude de tensão do Sátiro, entre o medo e a curiosidade, evidenciada pelo contraste entre as pernas lançadas para a frente e o corpo recuado (Boardman, 1985, fig. 61 e 64).

Esta é mais uma das virtualidades da pintura de vasos: dar-nos a conhecer algu-
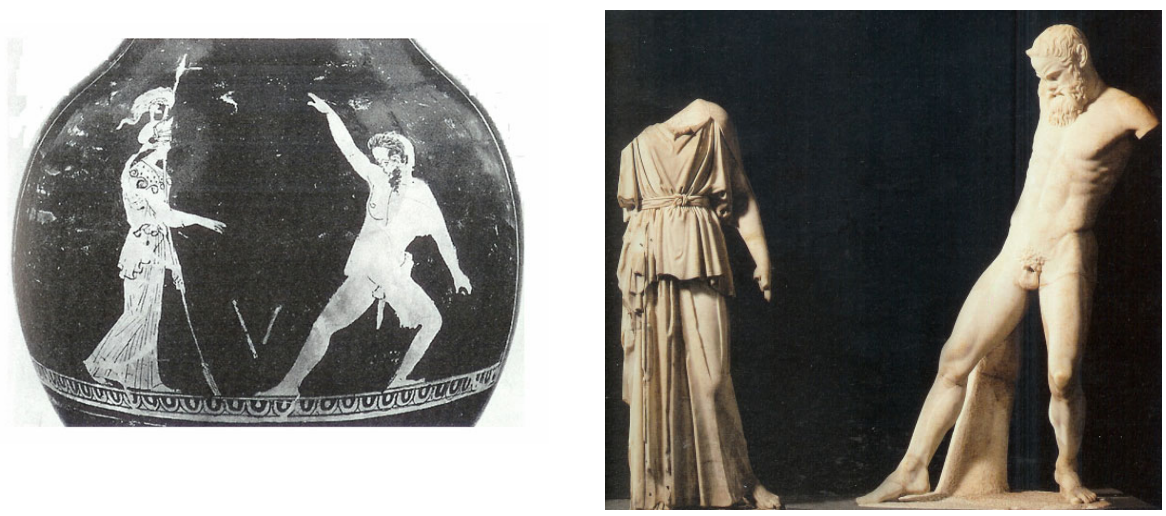

Fig. 10 e 11

mas das obras conhecidas e desconhecidas de grandes artistas da antiguidade. Da inesgotável fonte de informação que nos possibilitam os vasos gregos, muito ainda estará por desvendar.

Mas, de momento, fiquemos pela utopia de que um dia o nosso conhecimento sobre o legado grego se aproxime da realidade então vivida num dos momentos áureos dos primórdios da nossa Civilização. Bem hajam os Helenos!

3 Jogos fúnebres celebrados pelos nobres institucionalizados nos santuários em honra de um herói nomeado para a ocasiáo (Burkert, 1993, p. 398). 


\section{Bibliografia}

Bianchi Bandinelli, R. B. (1969). Rome. Le centre du pouvoir. Gallimard. Paris.

Boardman, J. (1988). Athenian Red Figure Vases. The Archaic Period. Thames and Hudson. London.

Boardman, J. (1991). Greek Art. Thames and Hudson. London.

Boardman, J. (1993). The Oxford History of Classical Art. Oxford University Press. Oxford.

Brommer, F. (1953). Herakles. Die zwölf Taten des Helden in antiker Kunst und Literatur. Münster/Köln, Bohlau-Verlag.

Brommer, F. (1960). Vasenlisten zur griechischen Heldensage. Marburg, N. G. Elwert Verlag. 1. Auflage, 1956. 2. verbesserte und erweiterte Auflage.

Burkert, W. (1993). Griechische Religion der archaischen und klassischen Epoche, Stuttgard 1977 (trad. portuguesa, Fundação Calouste Gulbenkian. Lisboa).

Carpenter, T. (2001). Arte y mito en la Antigua Grécia. Ediciones Destino. Barcelona.

Ferguson, J. (1975). Utopias of the Classical World. Thames and Hudson. London.

Graves, R. (2005). The Greek Myths (ed. port., 3 ${ }^{\mathrm{a}}$ ed.). Dom Quixote. Lisboa.

Plínio (2001). Textos de Historia del Arte (2a ed.). Edición de Esperanza. Torrego.

Rocha-Pereira, M. H. (1955). Concepçôes Helénicas de Felicidade no Além. De Homero a Platão. Coimbra.

Rocha-Pereira, M. H. (2005). "O mito na Antiguidade Clássica”. In José Ribeiro Ferreira (org.) Labirintos do mito. Coimbra, pp. 9-17.

Rocha-Pereira, M. H. (2003). Hélade. Antologia de textos gregos (10 ed.). Ed. Asa. Lisboa.

Rocha-Pereira, M. H. (2006). Estudos de História da Cultura Clássica. Cultura grega. Fundação Calouste Gulbenkian, I vol. (10ª ed.). Lisboa.

Rocha-Pereira, M. H. (2007). "Catálogo". Vasos Gregos em Portugal. Aquém das Colunas de Hércules. IPM/MNA. Lisboa, pp. 93-94.

Shapiro, H. A. (1994). Myth into Art. Poet and Painter in Classical Greece. Routledge. London.

Veyne, P. (1983). Acreditaram os Gregos nos seus mitos? Ediçôes 70. Lisboa. 


\section{Série}

\section{Documentos}

Imprensa da Universidade de Coimbra

Coimbra University Press

2009

- $\mathrm{U}$

C • 